\title{
Three Tales of Modernity
}

\author{
Howard Adelman
}

\begin{abstract}
The impact of globalization on the provision of assistance to newcomers is assessed in this paper. It takes a philosophical view of civilisation and argues that, a culture of caring is not an oasis in the emerging "global civilisation," but the source of its renewal. This culture of caring is contrasted with a more individualistic conception of isolation. Intervention of the state is required for curbing exploitative activities on isolated individuals. In contrast, the paper argues that civilisation might temporarily disrupt cultural values such as those geared to redistribution of wealth and the welcome we render to newcomers. However, recovery is possible through a set of moral rules and regulations which are independent of the state.
\end{abstract}

\section{Précis}

Cet article traite de l'impact de la globalisation sur l'assistance apportée aux nouveaux arrivants. Il se fonde sur une vision philosophique de la civilisation et développe une argumentation selon laquelle une culture du soutien (culture of caring) ne doit pas être vue comme un sorte d'oasis isolé dans la "civilisation globale" en émergence, mais plutôt comme la source vive de son renouvellement. Cette culture du soutien est ici mise en contraste avec l'isolationnisme individualiste. Généralement, c'est l'intervention de l'état qui est invoquée quand il s'agit de freiner l'exploitation intensive d laquelle l'individu isolé est exposé. Se plaçant quelque peu en porte-à-faux face à cette conception, l'auteur développe une

Howard Adelman is Director of the Prevention/ Early Warning Unit at the Centre for Refugee Studies, and Professor of Philosophy at York University, Toronto.

Excerpts of a draft paper for presentation at the conference on "Devolution of Settlement Services," Centre for Refugee Studies, February 16-18, 1996. argumentation selon laquelle la civilisation pourrait bien se mettre dे bousculer temporairement certaines valeurs culturelles reçues, telles celles préconisant la redistribution des richesses ou l'accueil inconditionnel des nouveaux arrivants. Cependant, un rajustement demeure possible via un ensemble de règles morales et de réglementations, indépendantes de celles émises ou préconisées par l'état.

The dominant narratives of modernity and the development of the Englishspeaking nation-state address the issues of the mind, the body, and how the mind and bodies of each individual and a multiplicity of individuals are made to cohere in the body politic.

As we approach the end of modernity and the old age of the nation state, it is well to recall the three different versions of the origin of the nationstate at the dawn of modernity. We can use the theories of British origins to illustrate those different narratives. One theory, rooted in the body, is that the nation-state is forged in war. Its theoretician is Thomas Hobbes-the body politic is formed when men, to secure themselves, that is, their bodies, both from outsiders and each other, make a compact whereby the will of the majority (a democracy), or the will of a specific elite (an oligarchy or aristocracy), or the will of one (a monarchy or dictatorship), is taken to be the will of every man in order to have a sovereign authority. In that way, a nation state is born (De Cive 1:3). In that nation-state, individuals retain one absolute right in the civil society-the right to self-defence and self-preservation.

In historical/empirical terms, Linda Colley in Britons: Forging the Nation 1707-1837 depicts the development of Britain from an Act of Union between England, Wales and Scotland in 1707 through the succession of wars with Catholic France culminating in the
Napoleonic Wars and the battle of Waterloo to forge the British nation. Men and women from different ethnic and social backgrounds found a unity in the imperial destiny of Britain. Ironically, in the twentieth century, stateengendered nationalism and the product of a nation-state forged in war, is most characteristic of those states of Africa that won their independence from empires.

In a second version of national origins, the development of the state is sui generis, emerging from the unique and particular characteristics of a people. It is a story of Münchhausen who can lift himself up by his own bootstraps. Its theoretician is John Locke- the body politic is forged when men together subject themselves to the rule of law (as opposed to the rule of men in Hobbes) to secure their property and rights, the most basic being a natural right to self-preservation along the model of an independent craftsman (rather than the more passive "security" of Hobbes). The individual introduces his labour into nature to convert that nature into an artifact as extensions of self in the form of property. Though, as in Hobbes, the polis derives its power from the delegation of its individual members, those members never surrender the right to regain those powers if those in power forfeit their trust. What is even more important, the productive power of society resides in labour power, the creative energy of the individual; the regulation of such power is also surrendered and can also be redeemed if its regulation is not carried out for the public good.

Aboriginal peoples, who had rights to treaties in their quest for self-preservation in Hobbes, lost their rights in the Lockean scheme of things because they belonged to a state of nature without a cash economy and a sense of property as possession and extension 
of the self. Nor did they have selfformed contractarian governments. Lockean theory thus provided an apologetic for the rape of land of the aboriginal people and the genocide of those people regarded as aliens in a state of nature. Ironically, it was also the foundation of modern human rights theory. Citizens had civil and political rights and a shared social solidarity in the state that guaranteed those rights. However, aboriginals were not citizens in this conception.

In empirical/historical terms, Liah Greenfeld (Nationalism: Five Roads to Modernity) provides the narrative for this self transformation of Britain from a group of foreigners studying together as a nation at a university abroad to a group with shared convictions differing from those of other nations, to an elite within the nation, and then to the people as a whole who are said to share these same values and thereby constitute a sovereign and unique people. Nationalism and the democratic right of a people to rule themselves are two complementary parts of the same vision. But so is the nullification of the other who is not considered to fall within the orbit of self-governance and the pursuit of property as happiness.

Though this liberal-nationalist, as opposed to state-nationalist, version of the nation-state had its roots in one version of British history, its clearest and most unequivocal example is the United States of America. ${ }^{1}$ Nation meant a polity formed by free and equal individuals versus a polity formed by uniting adjacent territories and giving union to a people in conflict with an enemy. Ironically, in the United States, the unity of the republic had to be won by the conquest of those who opposed freedom and equality of all individuals in order to preserve the tradition of slavery. At the same time, in the name of the liberty and equality of all individuals, the aboriginal peoples were driven off the land, even when, as in the case of the Cherokees, they were agriculturalists, but their view of the land was not an extension of self conceptualized in terms of land ownership and land values, but as the ground for ancestral roots and collective responsibility. ${ }^{2}$

In these two versions we forge our identities in relationship either to the enemy-other or in the denial of the reality of the other in favour of the selfsufficient self. But there is a third tale. The identity of the nation-state is forged in relationship to the proximate-other rather than either the enemy-other or the other-denied as the ground for asserting the reality of a self-sufficient self. The theoreticians for this story are to be found among the Scottish common sense theoreticians of sentiment, in particular, the muchdistorted Adam Smith and, more selfevidently, David Hume. They reject the foundationalism of both Hobbes and Locke while adhering to their empiricism. On the other hand, they asserted that there were a priori principles which were the conditions of having any experience whatsoever, a conviction that turned Kant's head around, but without his carrying on the Scottish conviction that there could be no certain foundation for truth or fundamental basis for a political and moral order. The moral (and political) order are founded on agreements of sentiments rather than a contract for self-preservation or self-protection of one's property and person. Mutuality is established when our sentiments correspond with one another. One cannot sympathize with another unless one imagines oneself in another's place. Emotional empathy or care is fundamental to justice rather than allowing care to express itself within a legal regime of justice which protects individual rights or a regime of the allpowerful state in which sentiment is deplored and rights are trampled. For Hume, the issue was the extension of the impressions on the self to enable a concern for the feelings and well-being of others to be forged.

The empirical social historian of this version of the development of the British nation, though traceable directly back to Hume's own histories, in contemporary terms is probably best evidenced in the writings of Robin Cohen (Frontiers of Identity: The British and the Others) and his historical account of the evolution of British sentimentality. That familiar other shifted from the Celts to the Dominions, from the Commonwealth to the Atlantic pact, but when the European, the traditional enemy-other, became the familiar other in the vision of a European Union, the extraterrestrial concept of the alien as totally other imported from Europe challenged the previously ambiguous boundaries of self and other. Ethnic-nationalism had been superimposed on Tory, Whig and Progressive Britain.

\section{Notes}

1. Clinton Rossiter (1953) Seedtime of the Republic: The Origin of the American Tradition of Political Liberty; Louis Hartz (1954) The Liberal Tradition in America; Edmund Morgan (1956) The Birth of the Republic; Seymour Martin Lipset (1963) The First New Nation: The United States in Historical and Comparative Perspective; Bernard Bailyn (1967) The Ideological Origins of the American Revolution; Henry Steele Commanger (1975) Jefferson, Nationalism, and the Enlightenment.

2. An early version of the extensive literature that developed subsequently on this subject, Mary E. Young, "Indian Removal and Land Allotment: The Civilized Tribes and Jacksonian Justice," American Historical Review, LXIV, October, 1958. 